\title{
Contemporary surgical outcomes of venous tumour thrombectomy managed with intraoperative Doppler ultrasound for kidney cancer
}

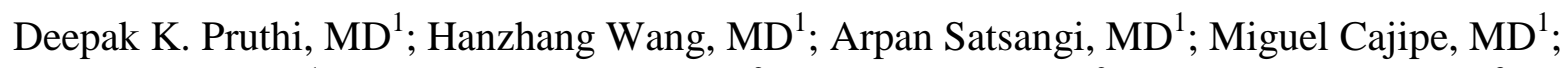
Kevan Iffrig, MD ${ }^{1}$; Georges M. Haidar, $\mathrm{MD}^{2}$; Taylor Hicks, MD²; Edward Y. Sako, MD³ Michael A. Liss, MD ${ }^{1}$; Wasim H. Chowdhury,MD ${ }^{1}$; Ronald Rodriguez, MD ${ }^{1}$; Dharam Kaushik, $\mathrm{MD}^{1}$

${ }^{1}$ Department of Urology; ${ }^{2}$ Department of Vascular Surgery; ${ }^{3}$ Department of Cardiothoracic Surgery; University of Texas Health San Antonio, San Antonio, TX, United States

Acknowledgements: This research was supported by the Cancer Prevention Research Institute of Texas (CPRIT) Research Training Award (RP 170345).

Cite as: Can Urol Assoc J 2018 May 14; Epub ahead of print. http://dx.doi.org/10.5489/cuaj.5013

Published online May 14, 2018

$* * *$

\section{Abstract}

Introduction: Radical nephrectomy ( $\mathrm{RN}$ ) with venous tumour thrombectomy (VTT) carries a significant morbidity and mortality risk. Examination of a contemporary single-institution series permits the development of a management algorithm and an audit its results. We report outcomes following the use of intraoperative colour Doppler ultrasound and our surgical pathway.

Methods: We retrospectively reviewed the records of all patients who underwent RN with VTT for kidney cancer between January 1, 2013 and October 1, 2016. Surgical complications, postoperative complications (Clavien-Dindo classification $\geq 3$ ), 90-day readmission rates, and outcomes are reported. Multivariate linear regression, logistic regression, and Cox proportional hazard modelling were used to identify associations.

Results: Fifty-eight patients underwent RN with VTT. Of these, 26 (45\%) patients had Mayo Clinic level III or IV thrombus and nineteen required venovenous/cardiopulmonary bypass. Three patients required patch grafting. The median length of hospital stay was eight days and there were 20 major complications. The 30-day readmission rate was $21 \%$ and the 90 -day mortality rate was $8.9 \%$. In multivariate analysis, low serum albumin and age-adjusted Charlson comorbidity score predicted length of stay. Increased intraoperative blood loss was significantly associated with increasing body mass index, serum creatinine, tumour thrombus level, and a history of significant weight loss $>9.1 \mathrm{~kg}$. Low serum hematocrit predicted 90 -day mortality. 
Conclusions: Intraoperative colour Doppler ultrasound is a useful tool and can facilitate caval preservation. Caval grafting can be avoided in most cases. Venovenous bypass can be avoided in many level III cases. Early therapeutic anticoagulation should be instituted with caution.

\section{Introduction}

Venous tumour thrombus occurs in $4 \%-10 \%$ of patients with renal cell carcinoma and extends to the right atrium in up to 1 to $3 \%$ of cases. ${ }^{1}$ Patients who do not undergo surgery have a dismal prognosis. $^{2-5}$ Despite the significant morbidity and potential mortality, aggressive surgical resection with radical nephrectomy $(\mathrm{RN})$ and tumour thrombectomy remains the mainstay of treatment even in the era of targeted therapy. ${ }^{6-11}$

The existing literature on this topic commonly examines perioperative outcomes, diseasespecific survival, and predictors of overall survival. ${ }^{12}$ However, these studies have been multiinstitutional and accrued patients over several years. ${ }^{13-16}$ The generalizability of these results is limited, given the differences in surgical technique and substantial advances in quality of postoperative care (anesthesia, intensive care, interventional radiology, and diagnostic imaging) in the contemporary era.

We established an integrated multidisciplinary surgical pathway for patients with renal mass and venous tumour thrombus that includes the use of intraoperative colour Doppler ultrasound. We report our experience, short-term outcomes, and subsequent changes in management.

\section{Methods}

After obtaining institutional review board ethics approval, we reviewed consecutive patients who underwent RN with venous tumour thrombectomy (VTT) between January 1, 2013 and October 1, 2016 at our center. Patients younger than 18 years were excluded. The thrombus level was classified using the Mayo Clinic classification system. ${ }^{6}$ Pre-operative clinical information was abstracted from the medical record and was complete. Major (grade $\geq 3$ ) postoperative complications were recorded if occurring within 90 days of surgery and categorized per the Clavien-Dindo classification. ${ }^{17}$ Thirty-day readmission data and outpatient follow-up information was obtained from clinic records. Records from any hospital visits at outside institutions were captured.

VTT pathway: Preoperative assessment, surgery, and postoperative care Surgical candidates are selected based on performance status, probability of curative resection, and likelihood of improved quality of life. Patients with poor performance status, significantly advanced disease (with concern for unresectability), and a high surgical morbidity or mortality risk are reviewed by our multidisciplinary tumour board. All patients undergo preoperative renal protocol computed tomography (CT) abdomen/pelvis (2 mm slices) with arterial, venous, and portal venous phases to evaluate the thrombus. Magnetic resonance imaging of the abdomen/pelvis is only performed when the patient has renal insufficiency precluding contrast- 
enhanced CT. CT chest is performed to complete staging and lower extremity Doppler ultrasound (US) is performed to rule out deep vein thrombosis (DVT). The maximum allotted time between imaging and surgery is 2 days for tumour thrombus $\geq$ level II and up to 30 days for $<$ level II. Patients undergo a complete blood count, complete metabolic panel, and urine culture. Anesthesia and cardiology consultations are performed for risk stratification and include cardiac stress testing and a transthoracic echocardiogram (to evaluate ejection fraction).

Multidisciplinary imaging review includes urology, radiology, and vascular surgery to determine the full extent of thrombus; cardiac surgery is involved for level III or IV tumour thrombus cases. Decisions regarding the surgical approach, the need for cardiopulmonary or venovenous bypass, and involvement of cardiothoracic surgeons are made at that time. All surgeries are performed by the same experienced urologic oncologists and vascular surgeons. Cardiac anesthetists are involved in all cases $\geq$ level I. Intraoperatively, all patients undergo colour Doppler US to delineate the extent of venous thrombus, guide cavotomy, and assess other vessels (Figure 1). The decision to place a graft is made intraoperatively. Use of cell saver is left to the discretion of the primary surgeon.

Postoperatively, the majority of cases are sent to the surgical intensive care unit. Patients are placed on sequential compression devices and receive subcutaneous anticoagulant DVT prophylaxis that is continued until discharge or 30 days postoperatively. Patients with bland thrombus, DVT, or pulmonary embolism (PE) are started on a therapeutic dose of anticoagulant preoperatively. Postoperatively, the duration of anticoagulation is left to the discretion of the anticoagulation clinic. Patients who undergo grafting for reconstruction of the inferior vena cava (IVC) receive aspirin $81 \mathrm{mg}$ daily for 3-6 months.

\section{Statistical analysis}

Continuous variables are presented as the median and categorical variables as frequency counts and percentages. The Student's t-test was used to compare differences in means and the chisquare test was used to assess differences in proportions. Multivariate linear regression modeling was used to predict continuous outcomes (length of stay, estimated intraoperative blood loss, transfused product volumes, operating time). Logistic regression modeling was used to predict binary outcomes (major complications, intraoperative complications, total complications). A Cox proportional hazards model was used to estimate 90-day mortality and 30-day readmission rates. A death related to a complication from intraoperative placement of a central line was excluded from the analysis of 90-day mortality. All variables that met a significance of 0.10 in the univariate model were placed in the multivariate models. All tests were two-sided and $p \leq 0.05$ was considered statistically significant. The statistical analysis was performed using STATA version 14 (Statacorp., College Station, TX, USA). 


\section{Results}

Fifty-eight patients (median age 58 years) underwent RN with VTT during the study period. The patients were predominantly Hispanic (62\%) and many were current smokers (45\%); they had significant comorbidities (median Charlson comorbidity score 3) and were taking an average of three prescription medications. The majority (98\%) had complaints of constitutional symptoms, weight loss, gross hematuria, and/or flank pain. Sixteen percent of the patients reported severe weight loss (median $13.6 \mathrm{~kg}$ ). Eight (14\%) patients had poor exercise tolerance ( $<4$ metabolic equivalent of tasks) and seven (12\%) had a pre-existing PE. One patient underwent palliative surgery for intractable gross hematuria. Table 1 shows the baseline patient characteristics, including operative features and tumour pathology.

Selected clinical and intraoperative features

Twenty-six (45\%) cases had level III or IV tumour thrombus. Twenty-seven (47\%) patients had left-sided tumours, which were more likely than right-sided tumours to be level 0 or I (44\% vs 15\%; $\mathrm{p}=0.017$ ). However, there was no significant difference between left-sided and right-sided tumours in terms of mean size (left $11 \mathrm{~cm}$, right $8.9 \mathrm{~cm} ; P=0.069$ ) or mean estimated intraoperative blood loss (left $4376 \mathrm{~mL}$, right $3224 \mathrm{~mL}$; $=0.301$ ). Due to significant bleeding complications an institutional practice change was introduced. The initiation of therapeutic anticoagulation was no longer administered within the first 24 hours among patients with no history of PE. This cautious delay resulted in fewer significant bleeding ( $\geq 2$ units PRBC) events $(\mathrm{p}=0.04)$.

Metastasectomy was performed where possible. One patient with level III thrombus had a mediastinal mass resection and omentectomy while another patient with level III thrombus had a wedge resection of a right lung mass. Planned concomitant surgeries included 3 cholecystectomies, one closure of patent foramen ovale, and a single-vessel coronary artery bypass ( $80 \%$ occlusion of the right coronary artery).

Intraoperative and postoperative complications

While no patient experienced a tumour embolism, an intraoperative cardiac arrest occurred in one patient secondary to air embolism from dislodgement of veno-venous canula (prior to cavotomy and early in the operation). Urologic complications included one intraoperative contralateral right ureteric injury that was recognized immediately and required a ureteroureterostomy. In addition, one patient sustained a significant contralateral renal vein injury requiring nephrectomy (subsequently placed on dialysis). Another patient required ureterolysis secondary to significant retroperitoneal fibrosis. In multivariate analysis, no variables predicted intraoperative complications. Patients with a high American Society of Anesthesiologists (ASA) score of 4 tended to have longer operating times (1962 minutes [95\% CI 10, 3913]; $\mathrm{p}=0.049)$. Increased intraoperative blood loss was associated with increasing BMI (311cc [95\% CI 163,460] per unit BMI, p<0.001), increasing creatinine (41 cc [95\% CI 3, 78] per 1mmol/L creatinine, p=0.033), increasing thrombus level (864cc [95\% CI 56,1672] per Mayo 
Clinic Thrombus level, $\mathrm{p}=0.0037)$, and a history of significant weight loss $>9.1 \mathrm{~kg}$ (2433cc [95\% CI 343,4523], $\mathrm{p}=0.023)$.

Ten (17\%) patients experienced an unrecognized intraoperative complication and twenty patients (34\%) experienced a major postoperative complication (Table 2). There was no difference in likelihood of postoperative complications between left-sided and right-sided RN with VTT (41\% vs 29\%; p=0.51). Two patients with pre-existing PE developed subsequent PE and three patients had new-onset PE. One patient developed a pericardial effusion with tamponade physiology requiring pericardiocentesis. In multivariable logistic regression analysis, no variable predicted major postoperative complication.

\section{Disposition and mortality}

Table 3 shows the disposition of patients. Most patients were discharged home by 8 days postoperatively; however, 12 were readmitted and 3 died during readmission. The reasons for the other 9 readmissions were: pneumonia, intra-abdominal abscess/sepsis, chylothorax, appendicitis, hemorrhage resulting in symptomatic hypotension, small bowel obstruction due to adhesion from remote appendectomy, diaphragmatic hernia, PE, and methicillin-resistant Staphylococcus aureus wound infection. In multivariate logistic regression analysis, no variable predicted 30-day readmission. Table 4 identifies the predictors of length of hospital stay. Only low hematocrit predicted 90-day mortality (0.7603 [95\% CI 0.586, 0.986]; $\mathrm{p}=0.039)$. Table 5 details patient mortality etiologies.

\section{Discussion}

While RN with VTT is a high-risk procedure it remains the mainstay of treatment for appropriately selected patients. In this contemporary series of high-risk patients, we examined the interim outcomes following the development of a multidisciplinary institutional VTT protocol. Overall, our major complication rate was 34\%. The 90-day mortality rate was $8.6 \%$ with a caveat of one death in a patient who underwent palliative surgery and another because of a rare intraoperative anesthetic complication. Most patients fared well and were discharged home 8 days following surgery. In multivariate analysis, there were significant associations between intraoperative blood loss and thrombus level, BMI, and high serum creatinine. Increased length of stay was associated with increasing age-adjusted Charlson comorbidity index and low serum albumin. No pre-operative variables were statistically associated with major complications or 30day hospital readmission. However, low preoperative serum hematocrit predicted 90-day mortality.

Accruing relatively large numbers of these cases in a single institution in three years permitted an active examination of the performance of our multidisciplinary VTT pathway. In addition, this is a largely Hispanic series and no studies have specifically investigated outcomes in Hispanic patients who undergo RN with VTT. Hispanic ethnicity has been independently associated with increased length of stay and poorer outcomes in other surgeries ${ }^{18-20}$. In our series, Hispanic ethnicity was not independently associated with any outcome in multivariate analysis. 
In addition, only 3 patients required a patch graft. One was placed very early in the series, the second for apparent wall invasion, and the third because a large portion of the IVC had been removed. Reported rates for caval reconstruction with patch grafting or IVC interposition range from $44 \%$ to $100 \% .{ }^{21,22}$ While the reported patency rates for caval grafts are high at around $80 \%-90 \%$, more complex reconstruction is associated with increased morbidity. ${ }^{23-25}$

Our growing experience with tumour thrombectomy resulted in three significant changes in the management of these complex patients. The first is the use of intraoperative colour Doppler US which was utilized in all IVC thrombus cases. It has several advantages over traditional transesophageal echocardiography. While intraoperative transesophageal echocardiography is primarily used to delineate the cranial extent of the tumour and monitor for potential embolization, it cannot be used as a measuring tool to guide cavotomy. Intraoperative Doppler US has a unique role in this regard in that it limits the need for caval manipulation, thereby reducing the risk of inadvertent embolization of thrombus. Intraoperative Doppler US also facilitates the early identification of parasitic vessels that become engorged after IVC clamping which is felt to mitigate intraoperative blood loss. Moreover, it helps to identify thrombus in other vessels, such as the posterior lumbar, hepatic, and gonadal veins. Finally, it allows visualization immediately following caval closure to ensure there is no residual thrombus/clot.

The second major change instituted was decreased use of venovenous bypass. While bypass affords a number of advantages, including avoidance of significant hemodynamic fluctuations and facilitation of operation in a bloodless field, Ciancio et al noted that bypass results in longer operating times, a greater risk of hemorrhage, and increased risk of renal dysfunction. ${ }^{26}$ With the aid of intraoperative Doppler US, we were able to carefully draw a number of level III thrombi back to 5-10 mm below the hepatic veins, avoiding the need for VVB. Moreover, these changes have allowed us to avoid median sternotomy in some level III cases.

Finally, a number of the complications were attributable to massive hemorrhage, including one that resulted in diffuse cerebral hypoxia and brain death. Early in this series, patients were placed on therapeutic doses of anticoagulation in adherence to established recommendations. ${ }^{27}$ However, as of November 2015 this was no longer routine practice, and patients are only placed on therapeutic doses if they have bland thrombus, DVT, or PE. Therapeutic anticoagulation is initiated cautiously in the postoperative period and without consequence to date.

One final lesson learned while operating on these high risk tumours was evident in the bilateral nephrectomy. While identification of blood vessels was facilitated by the intra-operative ultrasound, obtaining control at times is challenging. In one left-sided level 4 thrombus case the Rommel tourniquet was straddled to the right renal vein to avoid a very large right lumbar which was the size of the renal vein. This resulted in a small tear which exacerbated during the thrombectomy with each repair resulting in multiple satellite tears. Due to considerable hemorrhage a contralateral nephrectomy was required. The lesson learned was profound: never 
straddle the renal vein with a Rommel; go above or below. The tension of the Rommel was causal in the initial tear which escalated beyond control.

Direct comparison with other studies is challenging. As mentioned, other studies have relied heavily on administrative data, are multi-institutional, or compiled data over decades. ${ }^{12-16}$ Measurement of patient comorbidity also varies between studies, with some using simple ASA or Eastern Cooperative Oncology Group scores, whereas the Charlson comorbidity score was used in the present series. While administrative data can be powerful, they lack the granularity into the complexity of such cases and do not necessarily capture clinicopathologic data, thrombus level, or current American Joint Committee on Cancer $8{ }^{\text {th }}$ edition staging. ${ }^{28}$ A recent large series of 146 patients accrued over 14 years reported a high-grade complication rate of $10 \% .{ }^{29}$ In the subset analysis of the most recent 6 years, the complication rate was $8 \%$, which supports the contention that perhaps advances in perioperative care may be contributing to increased perioperative survival. However, in that series, 125 patients (86\%) had infrahepatic thrombi and 53\% of cases were renal vein-only thrombi. A similar large series of 162 patients with suprahepatic caval thrombus accrued over 12 years from four centers has also been published. ${ }^{30}$ While studies such as these are excellent for rare cases, retrospective multicenter studies that accumulate patients over several years limit the ability to evaluate a standardized care plan, given that both surgical technique and ancillary care evolve over time.

This study has limitations in that it is a retrospective case series with no comparator group. Moreover, the relatively small sample size limited the power to detect associations with complications and readmissions. Furthermore, we were unable to compare our findings against those treated prior to implementation of the VTT pathway. Nevertheless, the aim of the study was to examine perioperative outcomes in a contemporary cohort following implementation of the VTT protocol. In addition, the experience of 58 cases in a contemporary setting (45\% with level III or IV tumour thrombus) in less than 3 years afforded the ability to actively review and modify our management of these high-risk patients.

\section{Conclusion}

In this predominantly Hispanic population, our multidisciplinary VTT protocol allowed for safe extirpation in most of patients, along with early discharge from hospital. Use of intraoperative Doppler US facilitated caval preservation. Venovenous bypass can be avoided in many level III cases. Cautious consideration should be given to initiation of therapeutic anticoagulation in the early postoperative period. A dedicated multidisciplinary team that is involved from preoperative assessment to discharge should be the standard for these challenging cases.

\section{References}


1. Glazer AA, Novick AC. Long-term followup after surgical treatment for renal cell carcinoma extending into the right atrium. The Journal of urology 1996;155:448-50.

2. Hatcher PA, Anderson EE, Paulson DF, et al. Surgical management and prognosis of renal cell carcinoma invading the vena cava. The Journal of urology 1991;145:20-3.

3. Nesbitt JC, Soltero ER, Dinney CP, et al. Surgical management of renal cell carcinoma with inferior vena cava tumour thrombus. The annals of thoracic surgery 1997;63:159200.

4. Reese AC, Whitson JM, Meng MV. Natural history of untreated renal cell carcinoma with venous tumour thrombus. Urologic oncology 2013;31:1305-09.

5. Qi J, Gu Z, Chen F, Shen H, et al. Management of renal cell carcinoma with tumour thrombus in renal vein and the inferior vena cava. Annals of vascular surgery 2010;24:1089-93.

6. Blute ML, Leibovich BC, Lohse CM, et al. The Mayo Clinic experience with surgical management, complications and outcome for patients with renal cell carcinoma and venous tumour thrombus. BJU international 2004;94:33-41.

7. Cost NG, Delacroix SE, Sleeper JP, et al. The impact of targeted molecular therapies on the level of renal cell carcinoma vena caval tumour thrombus. European urology 2011;59:912-18.

8. Haferkamp A, Bastian PJ, Jakobi H, et al. Renal cell carcinoma with tumour thrombus extension into the vena cava: prospective long-term followup. The Journal of urology 2007;177:1703-08.

9. Kirkali Z, Van Poppel H. A critical analysis of surgery for kidney cancer with vena cava invasion. European urology 2007;52:658-62.

10. Skinner DG, Pfister RF, Colvin R. Extension of renal cell carcinoma into the vena cava: the rationale for aggressive surgical management. The Journal of urology 1972;107:71116.

11. Berg AA. Malignant hypernephroma of the kidney, its clinical course and diagnosis, with description of the author's method of radical operative cure. Surg Gynecol Obstet 1913;17:463-71.

12. Parra J, Drouin SJ, Hupertan V, et al. Oncological outcomes in patients undergoing radical nephrectomy and vena cava thrombectomy for renal cell carcinoma with venous extension: a single-centre experience. European journal of surgical oncology 2011;37:422-28.

13. Armstrong PA, Back MR, Shames ML, et al. Outcomes after inferior vena cava thrombectomy and reconstruction for advanced renal cell carcinoma with tumour thrombus. J Vasc Surg Venous Lymphat Disord 2014;2:368-76.

14. Kaag MG, Toyen C, Russo P, et al. Radical nephrectomy with vena caval thrombectomy: a contemporary experience. BJU international 2011;107:1386-93. 
15. Hatakeyama S, Yoneyama T, Hamano I, et al. Prognostic benefit of surgical management in renal cell carcinoma patients with thrombus extending to the renal vein and inferior vena cava: 17-year experience at a single center. BMC urology 2013;13:47.

16. Al Otaibi M, Abou Youssif T, Alkhaldi A, et al. Renal cell carcinoma with inferior vena caval extention: impact of tumour extent on surgical outcome. BJU international 2009;104:1467-70.

17. Dindo D, Demartines N, Clavien P. Classification of surgical complications: A new proposal with evaluation in a cohort of 6336 patients and results of a survey. Annals of surgery 2004;240:205-13.

18. Parsons HM, Habermann EB, Stain SC, et al. What happens to racial and ethnic minorities after cancer surgery at American College of Surgeons National Surgical Quality Improvement Program hospitals? Journal of the American College of Surgeons 2012;214:539-47.

19. Ravi P, Sood A, Schmid M, et al. Racial/Ethnic Disparities in Perioperative Outcomes of Major Procedures: Results from the National Surgical Quality Improvement Program. Annals of surgery 2015;262:955-64.

20. Williams TK, Schneider EB, Black JH, et al. Disparities in outcomes for Hispanic patients undergoing endovascular and open abdominal aortic aneurysm repair. Annals of vascular surgery 2013;27:29-37.

21. Tsuji Y, Goto A, Hara I, et al. Renal cell carcinoma with extension of tumour thrombus into the vena cava: surgical strategy and prognosis. Journal of vascular surgery 2001;33:789-96.

22. Hyams ES, Pierorazio PM, Shah A, et al. Graft reconstruction of inferior vena cava for renal cell carcinoma stage pT3b or greater. Urology 2011;78:838-43.

23. Quinones-Baldrich W, Alktaifi A, Eilber F, et al. Inferior vena cava resection and reconstruction for retroperitoneal tumour excision. Journal of vascular surgery 2012;55:1386-93.

24. Bower TC, Nagorney DM, Cherry KJ, et al. Replacement of the inferior vena cava for malignancy: an update. Journal of vascular surgery 2000;31:270-81.

25. Sarkar R, Eilber FR, Gelabert HA, et al. Prosthetic replacement of the inferior vena cava for malignancy. Journal of vascular surgery 1998;28:75-81.

26. Ciancio G, Shirodkar SP, Soloway MS, et al. Renal carcinoma with supradiaphragmatic tumour thrombus: avoiding sternotomy and cardiopulmonary bypass. The annals of thoracic surgery 2010;89:505-10.

27. Woodruff DY, Van Veldhuizen P, Muehlebach G, et al. The perioperative management of an inferior vena caval tumour thrombus in patients with renal cell carcinoma. Urologic oncology 2013;31:517-21. 
28. Hwang YJ, Minnillo BJ, Kim SP, et al. Assessment of healthcare quality metrics: Lengthof-stay, 30-day readmission, and 30-day mortality for radical nephrectomy with inferior vena cava thrombectomy. Canadian Urological Association journal 2015;9:114-21.

29. Bishoy GA, Youssef R, Darwish O, et al. Multi-disciplinary surgical approach to the management of patients with renal cell carcinoma with venous tumour thrombus: 15 year experience and lessons learned. BMC urology 2016;16:1.

30. Abel EJ, Thompson RH, Margulis V, et al. Perioperative outcomes following surgical resection of renal cell carcinoma with inferior vena cava thrombus extending above the hepatic veins: a contemporary multicenter experience. European urology 2014;66:584-92. 


\section{Figures an d Tables}

Fig. 1. Transverse view of inferior vena cava with intraoperative Doppler ultrasound. (a) Extension of tumour thrombus with compression of the inferior vena cava. (b) Tumour thrombus at the level of the hepatic veins demonstrating absence of thrombus extension into the middle and left hepatic veins.

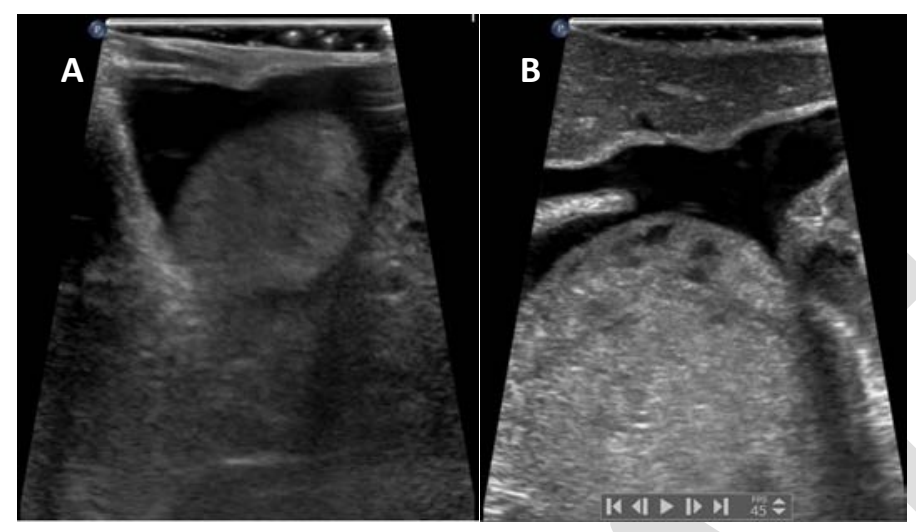




\begin{tabular}{|c|c|c|c|c|c|}
\hline Clinical & $\begin{array}{l}\text { Median } \\
\text { (IQR) }\end{array}$ & $\begin{array}{c}\text { Operative } \\
\text { features }\end{array}$ & $\begin{array}{c}\text { Median } \\
\text { (IQR) }\end{array}$ & $\begin{array}{c}\text { Tumour } \\
\text { pathology }\end{array}$ & n (\%) \\
\hline Age (years) & $\begin{array}{c}58(51.3, \\
67.8)\end{array}$ & $\begin{array}{l}\text { Operating time } \\
\text { (min) }\end{array}$ & $\begin{array}{c}344(257, \\
465)\end{array}$ & $\begin{array}{l}\text { Histological type } \\
\text { Clear-cell } \\
\text { Papillary } \\
\text { Mixed clear-cell } \\
\text { and papillary }\end{array}$ & $\begin{array}{c}46(79) \\
7(12) \\
5(9)\end{array}$ \\
\hline Thrombus & n (\%) & Surgical approach & n (\%) & Fuhrman grade $^{b}$ & \\
\hline level & & Chevron & $13(22)$ & 2 & $13(23)$ \\
\hline 0 & $8(14)^{\mathrm{a}}$ & Laparoscopic & $3(5)$ & 3 & $26(46)$ \\
\hline I & $8(14)$ & Midline & 19 (33) & 4 & $18(32)$ \\
\hline II & $16(28)$ & Subcostal & $3(5)$ & & \\
\hline III & $18(31)$ & Thoracoabdominal & $20(34)$ & & \\
\hline IV & $8(14)$ & $\begin{array}{l}\text { Median } \\
\text { sternotomy }\end{array}$ & $18(31)$ & & \\
\hline CCI & $2(1,4)$ & $\begin{array}{l}\text { IVC reconstruction } \\
\text { (graft, patch) }\end{array}$ & $3(5)$ & $\begin{array}{l}\text { Median tumour } \\
\text { size }(\mathrm{cm})\end{array}$ & $\begin{array}{l}9.4 \text { (IQR } \\
7.4,12.9)\end{array}$ \\
\hline ASA & $3(3,4)$ & $\begin{array}{c}\text { Bypass } \\
\text { Cardiopulmonary } \\
\text { Venovenous }\end{array}$ & $\begin{array}{l}\mathrm{n}(\%) \\
6(10) \\
13(22)\end{array}$ & $\begin{array}{c}\text { Pathologic stage } \\
\text { pT3a } \\
\text { pT3b } \\
\text { pT3c } \\
\text { pT4 }\end{array}$ & $\begin{array}{c}9 \\
38(81) \\
8(14)^{\mathrm{C}} \\
3(5)\end{array}$ \\
\hline BMI $\left(\mathrm{kg} / \mathrm{m}^{2}\right)$ & $\begin{array}{c}28.7(26.0, \\
32.6)\end{array}$ & $\begin{array}{l}\text { Estimated blood } \\
\text { loss (mL) }\end{array}$ & $\begin{array}{l}2625 \\
(1000 \\
5000)\end{array}$ & $\begin{array}{c}\text { Node status }^{\mathrm{d}} \\
\text { pNx } \\
\text { pN0 } \\
\text { pN+ }\end{array}$ & $\begin{array}{l}10(17) \\
39(67) \\
9(16)^{\mathrm{e}}\end{array}$ \\
\hline $\begin{array}{l}\text { Albumin } \\
\text { (g/L) }\end{array}$ & $\begin{array}{c}33.5(26.8, \\
37.3)\end{array}$ & $\begin{array}{l}\text { Transfused red } \\
\text { blood cells (mL) }\end{array}$ & $\begin{array}{c}1500(0, \\
3900)\end{array}$ & $\begin{array}{c}\text { Metastases at } \\
\text { presentation } \\
\text { M0 } \\
\text { M1 }\end{array}$ & $\begin{array}{l}34(59) \\
24(41)\end{array}$ \\
\hline $\begin{array}{l}\text { Serum } \\
\text { creatinine } \\
\text { (umol/L) }\end{array}$ & $\begin{array}{c}97.3(79.6, \\
115.0)\end{array}$ & $\begin{array}{l}\text { Transfused fresh } \\
\text { frozen plasma } \\
(\mathrm{mL})\end{array}$ & $\begin{array}{l}500(0, \\
2213)\end{array}$ & & \\
\hline $\begin{array}{l}\text { Hemoglobin } \\
\text { (g/L) }\end{array}$ & $\begin{array}{c}106 \\
(87,123)\end{array}$ & $\begin{array}{c}\text { Transfused } \\
\text { platelets (mL) }\end{array}$ & $0(0,250)$ & & \\
\hline $\begin{array}{l}\text { Hematocrit } \\
\text { (\%) }\end{array}$ & $\begin{array}{c}32.8 \\
(28.1,37.9)\end{array}$ & & & & \\
\hline $\begin{array}{l}\text { Calcium } \\
(\mathrm{mmol} / \mathrm{L})\end{array}$ & $\begin{array}{c}2.23 \\
(2.12,2.29)\end{array}$ & & & & \\
\hline $\begin{array}{l}\text { Platelets } \\
\left(\times 10^{3} / \mu \mathrm{L}\right)\end{array}$ & $\begin{array}{c}247 \\
(188,310)\end{array}$ & & & & \\
\hline
\end{tabular}

${ }^{a}$ All left-sided tumours; ${ }^{b}$ one papillary renal cell carcinoma, no grading; ${ }^{c}$ one IVC wall invasion. ${ }^{\mathrm{d}}$ median 8 (IQR 5, 18.5) nodes dissected. ${ }^{\mathrm{e}}$ median 21 (IQR 11, 25.5) positive nodes. 
ASA: American Society of Anesthesiologists; BMI: body mass index; CCI: Charlson comorbidity index; IQR: interquartile range; IVC: inferior vena cava.

\begin{tabular}{|c|c|c|c|c|}
\hline \multicolumn{2}{|c|}{ Intraoperative complications } & \multicolumn{3}{|c|}{ Postoperative complications } \\
\hline Complication & Management & $\begin{array}{l}\text { Clavien } \\
\text {-Dindo } \\
\text { grade }\end{array}$ & $\begin{array}{l}\text { Events } \\
(n=20)\end{array}$ & Description \\
\hline $\begin{array}{l}\text { Delayed lumbar } \\
\text { arterial } \\
\text { hemorrhage }\end{array}$ & $\begin{array}{c}\text { Urgent } \\
\text { angioembolization }\end{array}$ & $3 a$ & 1 & $\begin{array}{c}\text { Intra-abdominal abscess requiring } \\
\text { percutaneous drainage }\end{array}$ \\
\hline $\begin{array}{l}\text { Diaphragmatic } \\
\text { hernia }\end{array}$ & Urgent laparotomy & $3 \mathrm{~b}$ & 1 & $\begin{array}{l}\text { High-grade bile leak requiring } \\
\text { perihepatic drain insertion, several } \\
\text { ERCP sessions with stent changes }\end{array}$ \\
\hline $\begin{array}{l}\text { Leak } \\
\text { Lymph(n=2) } \\
\text { Pancreatic } \\
(\mathrm{n}=3) \\
\text { Bile }(\mathrm{n}=1)\end{array}$ & $\begin{array}{c}\text { TPN } \\
\text { Drain (octerotide } 1 \\
\text { case) } \\
\text { Drain, ERCP, } \\
\text { biliary stent }\end{array}$ & $4 a$ & $\begin{array}{l}4 \\
1 \\
2\end{array}$ & $\begin{array}{c}\text { Respiratory failure } \pm \text { tracheostomy } \\
\text { ICU stay following reoperation } \\
\text { Massive hemorrhage requiring ICU } \\
\text { admission } \\
\text { Chylothorax requiring repeated } \\
\text { intervention and ICU admission } \\
\text { Sepsis requiring ICU admission }\end{array}$ \\
\hline Chylothorax & Drain placement & $4 \mathrm{~b}$ & 4 & Multi-organ failure \\
\hline $\begin{array}{l}\text { Liver laceration } \\
\text { \& subcapsular } \\
\text { hematoma }\end{array}$ & $\begin{array}{l}\text { Repeated } \\
\text { transfusions }\end{array}$ & 5 & 5 & Death \\
\hline
\end{tabular}

*Note that the highest level of complication is reported per patient. ERCP: endoscopic retrograde cholangiopancreatography; ICU, intensive care unit; TPN: total parenteral nutrition. 


\begin{tabular}{|l|c|}
\hline \multicolumn{2}{|l|}{ Table 3. Disposition ${ }^{*}$ of patients and outcomes } \\
\hline Quality metrics & Median (IQR) \\
\hline Median LOS in ICU, days & $3(1.8,6)$ \\
\hline $\begin{array}{l}\text { Median LOS in hospital, } \\
\text { days }\end{array}$ & $8(6,14)$ \\
\hline $\begin{array}{l}\text { Disposition } \\
\text { Home }\end{array}$ & $\mathrm{n} \mathrm{( \% )}$ \\
Skilled nursing facility & $46(79)$ \\
Long-term acute care & $7(12)$ \\
Death & $3(5)$ \\
\hline 30-day readmission & $2(3)$ \\
\hline 30-day first quartile & $12(21 \%)$ \\
readmission & $7(58 \%)$ \\
\hline Readmission LOS & $9.5(3.8,25.5)$ \\
\hline Total 90-day mortality rate & $5(8.6 \%)$ \\
\hline
\end{tabular}

*Disposition at time of initial surgery; ${ }^{* *}$ Three patients required surgery (two bowel obstructions, one diaphragmatic hernia), and three further patients required percutaneous drainage (chylothorax, pancreatic leak, intra-abdominal abscess). ICU: intensive care unit; LOS: length of stay. 


\begin{tabular}{|c|c|c|c|c|}
\hline Length of stay & $\begin{array}{c}\text { Univariate } \\
\text { analysis }\end{array}$ & $\mathbf{p}$ & $\begin{array}{l}\text { Multivariate } \\
\text { analysis }\end{array}$ & $\mathbf{p}$ \\
\hline Age (years) & $0.11(-0.10,0.32)$ & 0.306 & & \\
\hline $\begin{array}{l}\text { Sex (ref: } \\
\text { Female) }\end{array}$ & $-0.13(-5.70,5.43)$ & 0.962 & & \\
\hline $\begin{array}{l}\text { Ethnicity } \\
\text { (ref: non- } \\
\text { Hispanic) } \\
\end{array}$ & $1.32(-4.21,6.84)$ & 0.635 & & \\
\hline $\operatorname{BMI}\left(\mathrm{kg} / \mathrm{m}^{2}\right)$ & $0.33(-0.06,0.71)$ & 0.095 & $0.16(-0.20,0.51)$ & 0.343 \\
\hline ASA & $2.05(-2.56,6.66)$ & 0.377 & & \\
\hline $\begin{array}{l}\text { Smoking (ref: } \\
\text { no) }\end{array}$ & $-2.45(-7.67,2.76)$ & 0.350 & & \\
\hline $\mathrm{CCI}^{*}$ & $1.75(0.46,0.03)$ & 0.009 & $1.86(0.69,3.03)$ & 0.02 \\
\hline $\begin{array}{l}\text { Weight loss } \\
>9.1 \mathrm{~kg} \text { (ref: } \\
\leq 9.1 \mathrm{~kg} \text { ) }\end{array}$ & $2.40(-3.05,7.84)$ & 0.382 & & \\
\hline $\begin{array}{l}\text { Number of } \\
\text { Medications }\end{array}$ & $0.16(-0.69,0.10)$ & 0.713 & & \\
\hline $\begin{array}{l}\text { Hemoglobin } \\
(\mathrm{mmol} / \mathrm{L})\end{array}$ & $\begin{array}{c}-0.097(-0.2 \\
0.004)\end{array}$ & 0.059 & $0.08(-0.55,0.71)$ & 0.8 \\
\hline Hematocrit (\%) & $-0.33(-0.68,0.03)$ & 0.068 & $-0.28(-2.37,1.80)$ & 0.910 \\
\hline $\begin{array}{l}\text { Creatinine } \\
\text { (umol/L) }\end{array}$ & $0.81(-0.019,0.18)$ & 0.110 & & \\
\hline $\begin{array}{l}\text { Calcium } \\
(\mathrm{mmol} / \mathrm{L})\end{array}$ & $\begin{array}{c}-6.4(-23.89 \\
11.08)\end{array}$ & 0.466 & 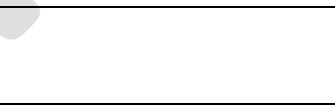 & \\
\hline Albumin (g/L) & $-0.47(-0.8,-0.14)$ & 0.006 & $-0.4(-0.71,-0.1)$ & 0.011 \\
\hline $\begin{array}{l}\text { Thrombus level } \\
\text { (ref: Level 0) }\end{array}$ & $1.48(-0.63,3.58)$ & 0.165 & & \\
\hline
\end{tabular}

Bolded text delineates statistical significance. ${ }^{*}$ Age-adjusted. ASA: American Society of Anesthesiologists; BMI: body mass index; CCI: Charlson comorbidity index; Ref: reference. 


\begin{tabular}{|c|c|c|c|c|}
\hline $\begin{array}{l}\text { Age, } \\
\text { years }\end{array}$ & Laterality & Level & $\begin{array}{l}\text { Postoperative } \\
\text { day number }\end{array}$ & Cause \\
\hline 56 & $\mathrm{~L}$ & 3 & 2 & $\begin{array}{l}\text { Inadvertent intraoperative perforation of } \\
\text { subclavian vein during central line } \\
\text { placement. Uneventful extirpation but } \\
\text { patient developed tension hemothorax, } \\
\text { sternotomy, anoxic brain injury }\end{array}$ \\
\hline 46 & $\mathrm{~L}$ & 2 & 70 & $\begin{array}{c}\text { Readmitted secondary to large bowel } \\
\text { obstruction requiring } 2 \text { exploratory } \\
\text { laparotomies }\end{array}$ \\
\hline 64 & $\mathrm{~L}$ & 3 & 19 & $\begin{array}{l}\text { Significant intraoperative blood loss, } \\
\text { intraoperative sinus ventricular tachycardia } \\
\text { requiring cardioversion } 10 \text { times. }\end{array}$ \\
\hline 79 & $\mathrm{~L}$ & 4 & 21 & $\begin{array}{l}\text { Massive retroperitoneal hemorrhage } \\
\text { resulting in diffuse cerebral hypoxia }\end{array}$ \\
\hline 53 & $\mathrm{~L}$ & 4 & 54 & RN with VTT was a palliative resection \\
\hline
\end{tabular}

*All deaths occurred during the hospital stay or during readmission. 